\title{
ANALYZING POLYGAMY REQUIREMENTS IN INDONESIA BY READING WOMEN IN TEXT AND CULTURE
}

\author{
Murniati, Henry Agus Sulistiono, Wahidullah \\ Fakultas Syari'ah dan Ilmu Hukum \\ Universitas Islam Nahdlatul Ulama Jepara \\ Jln. Taman Siswa Tahunan Jepara \\ Email:wahidullah@unisnu.ac.id
}

\begin{abstract}
This paper discusses re-conception of the requirements of polygamy marriage in Indonesia. It is expected to reach a fair for husband, wife, and children as well as to achieve the spirit of marriage goals. Juridical normative research methods are used to see injustice in the requirements of polygamy in UUP No.1 of 1974, namely 3, 4, and 5, and which do not correlate with Article 1 of that law. The research suggests that the understanding the text as well as patriarchal culture are the leading contributors to the injustice and must be resolved, so the dignity of marriages that is beneficial by protecting the parties without discrimination and humanity can be realized.
\end{abstract}

Keywords: The Dignity of Marriage, Justice, Understanding Text, Patriarchal Culture.

\section{Introduction}

Al-Qur'an indeed allows men to marry more than one wife with very heavy conditions, surah An Nisa verse 3 means " If you fear that you shall not be able to deal justly with the orphans (if you marry them), marry women of your choice, Two or three or four; but if you fear that you shall not be able 
to deal justly (with them), then only one, or (a captive) that your right hands possess, that will be more suitable, to prevent you from doing injustice".

This verse provides an explanation that women who can be in polygamy have orphaned provisions, and polygamous husbands can give rights as orphans and as wives. It is permissible to polygamy to the desired woman until the number four is be confirmed if it can act fairly. While being fair in polygamy certainly has various interpretations. There is a fair meaning based on mere economic aspects, by him, if the husband can provide for his wives then it is considered fair, or if the husband can divide his time to sleep alternately and evenly is considered fair, however, there are aspects of psychology that cannot be released that fair in polygamy is a correlation with physical and mental.

If a man is economically capable and able to set a schedule to share the love with his wives, that view is certainly from the husband's side. While from the other wives, is that justice acceptable? so the question arises whether a wife is willing to let go and willingly her husband remarries? Or is it only compulsion the wife give in with consideration like having a child, instead of the child being a victim, the wife finally gives up verbally not based physically and mentally sincerely releases her husband to remarry?

The beginning of compulsion of the wife, especially 
the first wife, became a victim of psychological injustice ${ }^{1}$ such as being depressed, and fearing while maintaining a wife who was willing to be forced into polygamy. The impact was born new problems such as mutual envy between wives, between children, the struggle for an inheritance, and even other physical violence can occur.

From Sura An-Nisa verse 3, the last option is if it is not able to do justice then men are expected to marry their slaves. The next question is whether there are slaves now? Certainly not, because slavery was abolished on the provisions of the abolition of slavery in 1833 in England. Meaning that there is very little chance of a man to be polygamous, and even that gap is almost non-existent.

\section{Literature Review Justice theory}

The power of law can never be separated from human life, therefore talking about the law can not be released from human life. ${ }^{2}$ in the realm of human life, every human being has an interest. Interest is an individual or group's demand that is expected to be fulfilled from birth, adulthood, and will face the divine or die, its importance will continue to develop following the development of life itself. To safeguard the idea

1 Nur Kholis, Jumaiyah and Wahidullah, "Poligami dan ketidak adilan gender dalam undang-undang perkawinan di Indonesia, Al, Abkam vol 27 No 2 Oktober, 2017, p 195-212

${ }^{2}$ Sudikno Mertokusumo, 2014, Mengenal bukum suatu Pengantar, edisi revisi,Cet. Ke.V, Universitas Atmajaya, Yogyakarta, p.1. 
of human interests requires a sense of security or protection ${ }^{3}$ a motivational hierarchy theory Abraham Maslow explains that security and protection are the second levels of human needs. ${ }^{4}$ Therefore humans need protection for the achievement of guidelines or regulations in life. It is hoped that with these regulations no behavior is detrimental to others or yourself..$^{5}$ The guidelines or benchmarks for behaving in a shared life are called the norm. ${ }^{6}$ As protection of human interests, standards, limits can be universally concluded as "laws" which have a clear purpose of protection, As for the main purpose of the law is to create an orderly society and create balance. ${ }^{7}$

\section{Methodology}

This research method uses the normative juridical research method, in a broad sense it is a legal review by not only looking at its relationship to the norm but rather looks at the importance of the social benefits of establishing legal norms. The juridical method in the narrow sense is working

${ }^{3}$ Ibid.p.4.

${ }^{4}$ Abraham Maslow was born on1 April 1908, and he died on the date 8 Juni 1970 at age 62 year, he is a theorist who gives a lot of inspiration in personality theory. He is also a psychologist who came from America and become a stream of humanistic pioneers. He is famous for his theory of the hierarchy of human needs. As stated in his book motivation and personality. http://belajarpsikologi.com/bioggrafi-abraham-maslow-dan-teorinya/.

Downloaded date 15 Juni 2020

${ }^{5}$ Sudikno Mertokusumo.op.cit.hlm.1

${ }^{6}$ Nicole Deitelhoff \& Lisbeth Zimmermann, Thing We Lost in the Fire: How Different Types of Contestation Affect the Robustness of international Norms. International Studies Review.2020, p. 51-76

${ }^{7}$ Philip Selznick. Law, Society, and Industrial justice. (Quid Pro Book 2020), p. 5 
with a dogmatic understanding system and mere formal assumptions, it is difficult to solve problems that are related to society. ${ }^{8}$ therefore this study examines the elements of the law to produce legal norms and the rule of law by identifying the main notions or basic requirements of polygamy in Indonesia.

\section{Results and Discussion}

\section{a. Marriage and Human Dignity}

Marriage is a necessity for normal people, so marriage is arranged in the religious scriptures of any country. The marriage comes from Arabic zawaja and nakaha to show a marriage between humans. The word nakaha means to gather. While the word zawaja means couple. Thus, in terms of language, marriage means the gathering of two people (individuals) who were originally individual into one unit.' With this union, which means that at first, they were two separate parts then by marriage they became a unified and complementary whole, which is called a couple ( zauja and zaujab).

The purpose and principle of marriage is an inseparable unity to find the basis of marriage philosophy. The purpose of marriage expressed by experts is to create a family that is full of peace, love, and affection (sakinah

${ }^{8}$ Soerjono Soekanto dan Sri Mamudji, 2015, Penelitian Hukum Normatif Suatu Tinjauan Singkat, Rajawali Pers, Jakarta, p.13-14.

${ }^{9}$ Abd Shomad, 2017. Hukum Islam (Penormaan Prinsip Syariah dalam Hukum Indonesia). Penerbit Kencana Prenada Media Group : Jakarta. p. 5 
mawaddah warohmanh). Besides that, the purpose of marriage is prescribed for the sake of avoiding free sex or promiscuity prohibited by religion, especially in Muslim families. To build the integrity of the household, Muslims are guided by Q.S. alRum (30):2110: "And one of His signs is that He created mates for you from yourselves that you may find rest in them, and He put between you love and compassion; most surely there are signs in this for a people who reflect." Of course, this goal was agreed by ijma' ulama. Therefore, these goals are the main objectives that will make human conduct marriage to be calm, happy and can love each other, respect and complement each other and protect.

According to al-Ghazali there are at least five main functions of marriage: first, obtaining offspring, therefore humans obtain survival, second, fortifying oneself from temptation, Satan, these temptations have especially lusted that often plunges a man into the abyss of immorality, Third, calm and placate the soul, condition of the marriage human beings will be calmer because every life problem is certainly not faced alone. Fourth, divide up household tasks, in this case, men can be heads of family and women can be heads of households or vice versa. So between husband and wife complement each other. Fifth, the arena for practicing responsibility. Every work in the household can be done together with full responsibility for each other. ${ }^{11}$

\footnotetext{
${ }^{10}$ Al-Qur'an Surah Arrum (30):21

${ }^{11}$ Abu Hamid al-Ghazali, Ihya" lbya' 'Ulum al-Din (Beirut:Daral-Fikr. 1975), IV: 102-114. Dan al-Jurjawi, Hikmatu ai-Tasyr' wa Falsafatubu (Beirut: Dar al-Fikr, 1994), II: 4-5.
} 
The urgency is the attainment of the goal of honor and human dignity itself as the prophet's statement narrated by Imam Bukhari and Imam Muslim ( Muttafaq "Alaihı): "Hi young men and women, who among you have the ability, then get married, marriage can close your eyes, and care for your genitals, while for those who cannot get married, perform fasting, because fasting can be an antidote to lust".

The dignity of marriages become the basis for religious teachings to avoid and hate divorce (separation). $\mathrm{He}$ stated that even if there was hatred between husband and wife in the household, they were encouraged to be patient, as mentioned in surah al-Nisa' (4):19: translation: "Believers, it is unlawful for you to inherit women forcefully, neither bar them, so that you go off with part of what you have given them, except when they commit clear indecency. Live with them honorably. If you hate them, it may be that you hate something which Allah has set in it much good". The starting point then points the body of marriage law in line with the philosophical basis and must avoid the points that can lead to the possibility of birth emergence of items discriminating against one of the partners.

The purpose of marriage which monogamy or polygamy, one of which is to bring offspring. But in practice many are abused, especially in the case of polygamy marriages, of course, it can give birth to social problems, not only for families directly involved with polygamies such as his wife and children but also social society at large. Many polygamy practices are only responsible for carrying out production 
activities (sex). Some polygamy actors (sirri), especially their husbands, refused to be the resource persons in this study. This is proof that polygamy has not been received in the community which will also have implications for the offspring produced and of course become its problems.

Therefore it needs efforts to avoid the emergence of problems like this. One of the efforts is the rule maker so that polygamists are truly responsible and capable people. Therefore, with the renewal of the requirements contained in the Marriage Law carried out to be able better guarantee the contextualization of the ability of polygamy. That polygamy must be carried out really because of the urgent emergency needs, not just biological needs, and the perpetrators are responsible for bearing all poses risks. Thus, the marriage can bring human dignity to the wife and offspring that it generates. Is not the function prescribed by a case is for the benefit, so is marriage presented as a benefits framework as described above, although polygamy marriages are permitted in UUP No.1 of 1974 and considered as a benefit it should not crash into another benefit, which is to uphold humanity and justice without discrimination.

\section{b. The Purpose of Marriage in Legal Regulations in Indonesia}

UU No. 1 of 1974 concerning marriage states that the definition of marriage is an inner and outer bond between a man and a woman as husband and wife to form a family (a happy and eternal household based on the divinity of the 
Almighty) ". ${ }^{12}$ The contents of this Act are very different from the Civil Code stated that: "The Law Looks at marriage only in civil relations." 13

According to Islamic Law (KHI) explains: "marriage is marriage, that is a very strong contract or mitsaaqon gholiidhan to obey God's commands and carry out them is worship". ${ }^{14}$ then marriage is a birth bond with a formal relationship that can be seen because it is formed according to the Act, a binding relationship between the two parties and other parties in the community, whereas inner bonds are informal relationships that are formed with sincere mutual desires, and binds both parties only, between a man and a woman, meaning that in one period of inner and outer bonding occurs only between a man and a woman. Where both of them are a result of the existence of inner and outer bonds as a function of husband and wife. However, there are differences in the conditions of marriage between the State Marriage Law and regulations according to Islamic Law (KHI), according to Marriage Law No.1 of 1974 that marriage is recorded in the marriage record while in fiqh munakahat does not require the registration, ${ }^{15}$ so that many men carry out unregistered marriages, where unregistered marriages cause many problems in community life such as online unregistered

\footnotetext{
12 Pasal 1 Undang-Undang Nomor 1 Tahun 1974 tentang Perkawinan

${ }^{13}$ KUHP Perdata

14 Pasal 2Keputusan mentri Agama nomor 154 Tahun 1991 tentang Kompilasi Hukum Islam.

15 Aisyah Arsyad, 2018, Binary Patriarchy In Nikah Siri: An Ecofeminism Perspective. JICSA: Journal Of Islamic Civilization in Southeast Asia. Vol 7, No 1 Juni, p. 1-26
} 
marriages, falsification of documents, and human trafficking. For this reason, the government must issue a special marriage law that requires citizens to hold marriages on the condition they are registered on the marriage registration and invalid if the marriage is not under the laws of the country.

\section{c. The position of his wife and children in terms of unfair polygamy}

In-Law No. 1 of 1974 about Marriage the principle of marriage is that a man can only have a wife, also a woman can only have a husband, ${ }^{16}$ the principle of monogamy is a principle that requires that at the same time a man is only allowed to have a woman as his wife and vice versa. Otherwise, in the Civil Code it is stated "at the same time a man is only allowed to have one woman as his wife, a woman is only one man as her husband. ${ }^{17}$

To carry out marriages the parties must follow the marriage requirements based on statutory regulations, There are two types of marriage conditions, namely material conditions and formal conditions. Material conditions are conditions that exist and are inherent in the parties to the marriage, also called subjective conditions ${ }^{18}$ Marriage requirements in Law No. 1 of 1974 concerning marriages are contained in Chapter II of Article 6 through Article 12.

\footnotetext{
16 Pasal 3 UU. No. 1 Tahun 1974

17 Pasal 27 KUH Perdata.

18 See KUH Perdata (pasal $27 \mathrm{~s} / \mathrm{d}$ pasal 42) and in Constitution
} number 1 year 1974 (pasal) 3 ayat 1 , pasal 6 ayat $1 \mathrm{~s} / \mathrm{d}$ ayat 5 , pasal 7 ayat 1 s/d 9, serta pasal 39 PP No.9 year 1975 
The requirements for a monogamy or polygamy marriage to take place, then the following conditions must be met: the agreement of the two brides (Article 6 Paragraph 1 of Law No. 1 of 1974 concerning marriage), the male is 19 years old, female is 16 years old (Article 7 Paragraph 1 of Law No. No.1 of 1974 concerning marriage), Parental / court permission if not yet 21 years old (Article 6 Paragraph 2 of Act No.1 of 1974 concerning marriage), not still bound in marriage (Article 9 of Law No. 1 of 1974 concerning marriage). Not divorced for the second time with the same husband/wife who wants to marry (Article 10 of Law No.1 of 1974 concerning marriage), for widows, the waiting time has passed (Article 11 Paragraph 1 of Law No.1 of 1974 concerning marriage), has notified the marriage registrar 10 days before the marriage takes place (Article 3 PP.No 9, 1975), no one proposed prevention (Article 13 of Law No. 1 of 1974 concerning Marriage), and there was no prohibition on marriage (Article 8 of Law No. 1 of 1974 concerning marriage).

While for polygamy marriage there are additional requirements, as stipulated in Article 3 of Law No. 1 of 1974 it states that "in the principle of marriage a man may only have a wife, a woman can only have a husband. This article affirms men that marriage is monogamous". The question then what if there are problems that can be solved by polygamies such as not having children due to infertility, or the wife can not carry out her duty as a wife? This question is answered by Article 4 paragraph 2 of Law No.1 of 1974 specifying the 
reasons that must be understood by the husband if he will remarry another woman. In this article the reasons are the only alternative, meaning that only one of them is fulfilled, that is enough. The reason is that the wife cannot carry out her duty as a wife, the wife gets a disability or an incurable disease, and the wife cannot give birth to offspring. If one of the reasons is fulfilled, the husband must fulfill the conditions stipulated in Article 5 of Law No. 1 of 1974, which is cumulative, meaning that all conditions must be met. As for the conditions: there is agreement from the wife, there is a certainty that the husband can guarantee the necessities of life of their wives and children, and there is a guarantee that the husband will be fair to his wives and children. Do not reverse polygamy to enrich himself or want to support his first wife with a second marriage by marrying a wealthy woman. As happened to Rudi's family (not his real name) that he remarried to strengthen the economy of his family because he believed that if he remarried the first wife would be economically independent meaning he wanted his wife to work, besides that the second wife who had more wealth to be used as capital in his life.

By paying attention to the reasons and conditions of polygamy marriage, it can be stated that polygamy, although allowed as an exception, is made difficult by law. Polygamy can be implemented if there is a court permit, the court can only permit if all the conditions supporting that reason are fulfilled. It seems difficult to get permission from the wife because it can be estimated that no wife wants to be 
combined. So what happens many sirri marriages (quietly) are not recorded in court.

The requirements for polygamy do not explain the provisions regarding the existence of children in a polygamy marriage request, this is what then the existence of his wife and children in marriage law No.1 of 1974 did not receive a portion of justice in involvement to build happiness as the principle of the purpose of marriage. In the context of happiness, only one party, namely the father alone, but the happiness that can be felt by several parties (families) including the child, parties to the will of polygamy as Article 3 Paragraph 2 of UUP No.1 of 1974 should be requested from the child's side, so that the court can give permission for polygamy not only based on the husband and wife alone but also involves the will of children like what?. Likewise in Article 5 item (a) UUP No.1 of 1974 concerning the approval of wives for polygamy of their husbands there needs to involve the approval of the children.

Injustice without taking sides with women (wives) can be found in Article 5 paragraph 2 states that: the agreement referred to in paragraph (1) letter a of this article is not required for a husband if his wives are not likely to be asked for an agreement and cannot be a party to the agreement, or if there is no news from his wife for at least 2 (two) years, or for other reasons that need to be assessed by a court judge. In that article, especially at the end of the article that reads: "....or due to other reasons that need to be judged by a court judge". The decision of the Verstek decision without the 
presence of the respondent is subjective in court, while the absence of the respondent in this matter (wife), and the request for polygamy was rejected by the court. The provisions of polygamy in Indonesia now do not favor the wife (women) moreover the protection of children, so that it can be normatively ascertained the rights of wife or child rights that are helping to create a happy family in castration.

\section{d. Understanding the Nash Text and Patriarchal}

\section{Culture}

The energy that must be expended to talk about women in an Islamic context requires courage, efforts to formulate the truth concept which can be accepted by almost half a billion Muslim women in all corners of the world as if it was only a long struggle without end. ${ }^{19}$ especially if the formulation of the concept rests on the doctrine that was formulated dozens of centuries ago or is only blind lived with a wave of modern western liberalism. The concept of equality being discussed is not equality or there is no gap (differentiation) as understood (demanded) by many feminists. This talk will lead to the concept which refers to that every human being must have differences between one another, both in the form of pleasure, culture, and skills in his life. However, the differences that each person has do not have to be understood as legitimating to legalize the status quo that the strong will control the weak, as men as powerful

19 Arvind Sharma (Ed.), 2006, Perempuan dalam Agama-agama Dunia, diterj. oleh Ade Alimah, Suka Press, Yogyakarta, p. 331. 
beings dominate women. Men must arrange women's lives or other similar conditions. Instead, the differences that exist must be understood as sunnatullah and the provisions applied differently must be understood as an effort to bring about justice, about justice classic concept guided by "putting something by the place and size" rather than generalizing something to two types of cases that have differences.

When Islam stipulates a provision, there must be wisdom behind the stipulation, including the rules that are applied differently to men and women. Until this episode, there were no serious symptoms related to the issue of gender equality. However, when entering into the realm of praxis, then the problem is much discussed, starting from the obligation of women to cover their aurat with headscarves, different inheritance rights between men and women, the power of witnesses in court differs between women and men, the difference between men and women in determining how many partners (polygamy) and many other life problems. This problem has shown the gap between the ideal concept of Islam with the concept of women's lives to get respect and their rights in real life.

In the context of gender equality in Islam, an inclusive paradigm can blow away the wind of freedom for women and men. This freedom does not violate the instincts of each but instead offers harmony that does not harm one of them. For example, many modern women who are highly educated, have prestigious positions or successful entrepreneurs who remain faithful in carrying out their motherhood (breastfeeding, 
caring for children, and preparing household needs) without having to experience inner conflict.

In the case of polygamy offered by Islam, the concept that represents the principle of "choice and avoids coercion "is reflected in the law of origin of polygamy which only has the status of worship and permission from the wife as an absolute condition for polygamy of a husband. With the aim of worship, a man does not have to force himself to worship, also, with the condition for asking permission, a wife is fine if she refuses the request of her husband who wants polygamy. It's just that the approval and rejection given must be based on logical reasons, not just based on the interests of egoismindividualism. Thus, the permissibility of polygamy husbands requires that permission from the wife has answered some people's uncertainty about the principle of gender equality in the issue of polygamy. In some societies, women with widowed status are socially in need of protection, especially if there are children with them. Like the Prophet Muhammad who married widows in addition to his marriage to Aisyah RA to protect widows, protect orphans, and knitting peace between tribes. $^{20}$

\section{Conclusion}

The existence of Law No.1 of 1974 concerning

20 Muhammad Arifin Badri, Korelasi antara pernikahan dengan perdamaian social masyarakat (studi kasus pernikahan Nabi Muhammad dengan juwairiyah binti al-haris dan ummu habibah binti abu sufyan), Al Majaalis Jurnal Dirasat islamiyah. Vol 5 No.1, November 2017. Hlm. 201-231 
marriage still leaves the issue of justice. Provisions regarding polygamy marriage requirements are still in favor of men (husband). Interpretation of patriarchal texts and culture is one of the main causes of the wife (women) and children in a weak position. This has implications for marriage and economic compulsion, even unavoidable psychological and the inevitable licensing of polygamy. Then returning conception of the meaning of marriage purpose while dismissing the understanding of the text based on patriarchal culture certainly provides the benefit of the parties, as the estuary of the law, namely justice that provides protection and humanity. Wallahu 'alam.

\section{REFERENCES}

Abd Shomad, 2017. Hukum Islam (Penormaan Prinsip Syariah dalam Hukum Indonesia). Penerbit Kencana Prenada Media Group : Jakarta.

Abu Hamid al-Ghazali, Ihya" lhya' 'Ulum al-Din (Beirut:DaralFikr. 1975), IV

....... Al-Jurjawi, Hikmatu ai-Tasyr' wa Falsafatuhu (Beirut:

Dar al-Fikr, 1994)

Aisyah Arsyad, 2018, Binary Patriarchy In Nikah Siri: An Ecofeminism Perspective. JICSA: Journal Of Islamic Civilization in Southeast Asia. Vol 7, No 1 Juni.

Al-Qur'an Surah Arrum (30):21

Arvind Sharma (Ed.), 2006, Perempuan dalam Agama-agama Dunia, diterj. oleh Ade Alimah, Suka Press, Yogyakarta.

Keputusan Mentri Agama Nomor 154 Tahun 1991 tentang Kompilasi Hukum Islam. 
KUH Perdata (pasal 27 s/d pasal 42) dan dalam UndangUndang Nomor 1 Tahun 1974 (pasal) 3 ayat 1, pasal 6 ayat $1 \mathrm{~s} / \mathrm{d}$ ayat 5 , pasal 7 ayat $1 \mathrm{~s} / \mathrm{d} 9$, serta pasal 39 PP No.9 Tahun 1975

Muhammad Arifin Badri, 2017 Korelasi antara pernikahan dengan perdamaian social masyarakat (studi kasus pernikahan Nabi Muhammad dengan juwairiyah binti al-haris dan ummu habibah binti abu sufyan ), Al Majaalis Jurnal Dirasat islamiyah. Vol 5 No .1, November.

Nicole Deitelhoff \& Lisbeth Zimmermann, 2020 Thing We Lost in the Fire: How Different Types of Contestation Affect the Robustness of international Norms. International Studies Review.

Nur Kholis, Jumaiyah and Wahidullah, 2017, Poligami dan ketidak adilan gender dalam undang-undang perkawinan di Indonesia, Al, Abkam vol 27 No 2 Oktober.

Philip Selznick. Law, Society, and Industrial justice. (Quid Pro Book 2020).

Soerjono Soekanto dan Sri Mamudji, 2015, Penelitian Hukum Normatif Suatu Tinjauan Singkat, Rajawali Pers, Jakarta.

Sudikno Mertokusumo, 2014, Mengenal bukum suatu Pengantar, edisi revisi,Cet. Ke.V, Universitas Atmajaya, Yogyakarta.

Undang-Undang Nomor 1 Tahun 1974 tentang Perkawinan 